\title{
Impact of Bed Material on the Local Scour Downstream Fayoum Type Weir with Various Designs of Floor Jets
}

\author{
Gamal Elsaeed ${ }^{1}$, Abdelazim M. Ali², Alaa Nabil El-Hazek ${ }^{3}$, Ahmed M. M. Ibraheem,* \\ ${ }^{1}$ Faculty of Engineering at Shoubra, Benha University \\ Cairo, Egypt \\ ${ }^{2}$ Hydraulics Research Institute, National Water Research Center, Ministry of Water Resources and Irrigation \\ Cairo, Egypt \\ ${ }^{3}$ Faculty of Engineering at Shoubra, Benha University \\ Cairo, Egypt \\ ${ }^{4}$ Hydraulics Research Institute, National Water Research Center, Ministry of Water Resources and Irrigation \\ Cairo, Egypt \\ ${ }^{*}$ Corresponding author's email: eng.ahmedmahmoud2009 [AT] yahoo.com
}

\begin{abstract}
Local scour downstream hydraulic structures should be studied well to avoid damage or even failure of these structures. In this paper, an experimental model was conducted to study the influence of bed material size on the local scour downstream stilling basins of Fayoum type weir as a hydraulic structure. Two bed material were tested. The model included stilling basin and five rows of water jets. Forty-five test runs were carried out for each bed material. Different cases were implemented during this study including three flow discharges, three tail water depths and five various designs of floor jets. Based on the obtained results, it was found that the maximum and minimum scour depths for the two bed materials occurred by design A and design $D$. The maximum scour lengths happened for medium sand by design $C$ and for fine gravel by both designs $A$ and $E$, while the minimum scour lengths were recorded for medium sand by design $D$ and for fine gravel by design A. The maximum scour volumes were found for the two bed materials by design A, while the minimum scour volumes occurred by both designs $C$ and $D$ for medium sand and by design $E$ for fine gravel. Employing fine gravel instead of medium sand as a bed material achieved maximum reduction percentages of $86.8 \%, 53.3 \%$ and $89.8 \%$ for scour depth, scour length and scour volume, respectively.
\end{abstract}

Keywords-Hydraulic Structures, Weirs, Stilling Basin, Floor Jets, Bed Material, Scour.

\section{INTRODUCTION}

Employing suitable tools to dissipate energy can reduce the cost of protection layer downstream the stilling basin. Floor jets will be useful in abstracting the flow to go away from the canal bed. There are many tools that can be used to dissipate energy such as chute blocks, baffle piers and end sills, Edward [1] and Peterka [2]. Also, they can be useful for stabilizing the flow, increasing the turbulence, and distributing the velocities evenly through the basin. A reduction in the required tailwater depth and length of the basin might be attained by adding one or more of these appurtenances to the basin, Edward [1]. Yasser A. Moussa et al [3] studied experimentally the performance of sill for Naga Hammadi Barrage as a case study. The Results indicated that sills, especially with right and slopped faces at both upstream and downstream, had a great effect on the examined variables. Ahmed [4] conducted a physical model to study the influence of using double lines of water jets on minimizing the scour-hole dimensions downstream of a Fayoum type weir. The results demonstrated that using 0.7 relative length and 0.15 relative discharge achieved $68 \%$ maximum reduction in the scour depth and $76 \%$ maximum reduction in the scour length. Akhmad Adi Sulianto et al [5] implemented experimental and numerical simulation to illustrate the characteristics of local scouring under several tsunami overflow conditions. Experimental equations to estimate the maximum scour depth and maximum scour length had been developed. Xiao-xie LIU et al [6] conducted experimental studies to investigate the injection 
effects on the bed load transport rate. The experimental results clarified the inverse proportion between injection velocity and the shear velocity excess. Esam [7] studied experimentally the effect of using single line of floor water jets on scour hole parameters downstream Fayoum type weir. The results concluded that the optimum location of 0.4 relative length achieved $90 \%$ reduction in maximum scour depth and $85 \%$ reduction in maximum scour length. Hossam et al [8] demonstrated that using spaced triangular strip corrugated bed reduced sequent depth and length of the hydraulic jump by $15 \%$ and $21 \%$, respectively. Also, jump efficiency was increased by 50\%. Sayed et al [9] studied the effect of upward seepage due to head difference between the upstream and downstream of a grade control hydraulic structure. The results indicated that the scour depth decreased significantly with the presence of upward seepage. S. M. R. Nabavit et al [10] carried out experimental study to investigate characteristics of scour hole downstream of free-falling jet with upward seepage showing an increase in scourhole dimensions. M. Ghodsian et al [11] studied experimentally the behavior of local scour due to free- fall jets in non-uniform sediment showing that the scour hole parameters decreased by increasing the sediment non-uniformity. Moreover, in nonuniform sediment, $\mathrm{d}_{90}$ could be used instead of $\mathrm{d}_{50}$. H. Hamidifar et al [12] conducted experimental model to investigate the erosion behavior of the non-cohesive sediments downstream of smooth and rough aprons. The results indicated that the characteristics of the scour holes were much smaller for rough than smooth aprons. A minimum reduction of $60 \%$ was observed for the maximum scour depth with respect to the smooth beds. Abdelazim M. Ali et al [13] carried out experimental study to investigate the effect of different shapes of stilling basins of regulator on the local scour downstream barrage basin. Experimental model was conducted by Subhasish Dey et al [14] to investigate scour on non-cohesive sediment beds downstream of an apron due to a submerged horizontal jet issuing from a sluice opening. The results illustrated that the average reduction of scour depth was 39\% by placing a launching apron. Samir et al [15] studied experimentally the effect of using a double leaf sluice gate instead of a single leaf. S. S. Chatterjee et al [16] investigated experimentally the local scour and sediment transport due to a horizontal jet issuing from a sluice gate and flowing over a rigid apron. Ali Uyumaz [17] studied experimentally the investigation of the local scour in non-cohesive soils below the vertical gates. It was concluded that the final depth of scour was smaller when there was simultaneous flow under and over the gate. Javad Farhoudi et al [18] carried out experimental study to explain the similarity existing either in the process of scour or in the profiles that the scour-holes followed downstream of hydraulic jump flow.

\section{Notations}

\begin{tabular}{|c|c|c|c|c|c|}
\hline Symbol & Description & Units & Symbol & Description & Units \\
\hline h & The weir operating head. & $\mathrm{m}$ & $\mathrm{L}_{\mathrm{j}}$ & $\begin{array}{l}\text { Distance from the weir toe to the } \\
\text { center of water jet lines. }\end{array}$ & $\mathrm{m}$ \\
\hline$\overline{\text { ds }}$ & The maximum scour depth. & $\mathrm{m}$ & $\mathrm{L}_{b}$ & $\begin{array}{l}\text { Distance from weir toe to the end } \\
\text { of stilling basin. }\end{array}$ & $\mathrm{m}$ \\
\hline $\mathbf{y}_{\mathbf{t}}$ & The tail water depth. & $\mathrm{m}$ & $\mathrm{L}_{\mathrm{f}}$ & The length of bed material. & $\mathrm{m}$ \\
\hline Q & The flow discharge. & $\mathrm{L} / \mathrm{s}$ & $\overline{L_{s}}$ & The maximum scour length. & $\mathrm{m}$ \\
\hline
\end{tabular}

\section{EXPERIMENTAL SETUP}

A definition sketch of the involved phenomenon and the related parameters are shown in Figure 1. The experimental study was carried out at the hydraulic laboratory of the Hydraulics Research Institute (HRI), National Water Research Center (NWRC), Ministry of Water Resources and Irrigation (MWRI), Egypt. A physical model of Fayoum type weir was used to study the influence of using two different sizes of bed material located directly downstream stilling basin on the scour parameters. The model included stilling basin and five lines of water jets. The distance between each line was constant as $0.4 \mathrm{~m}$ and the first line was located at $0.4 \mathrm{~m}$ apart from the weir toe. 


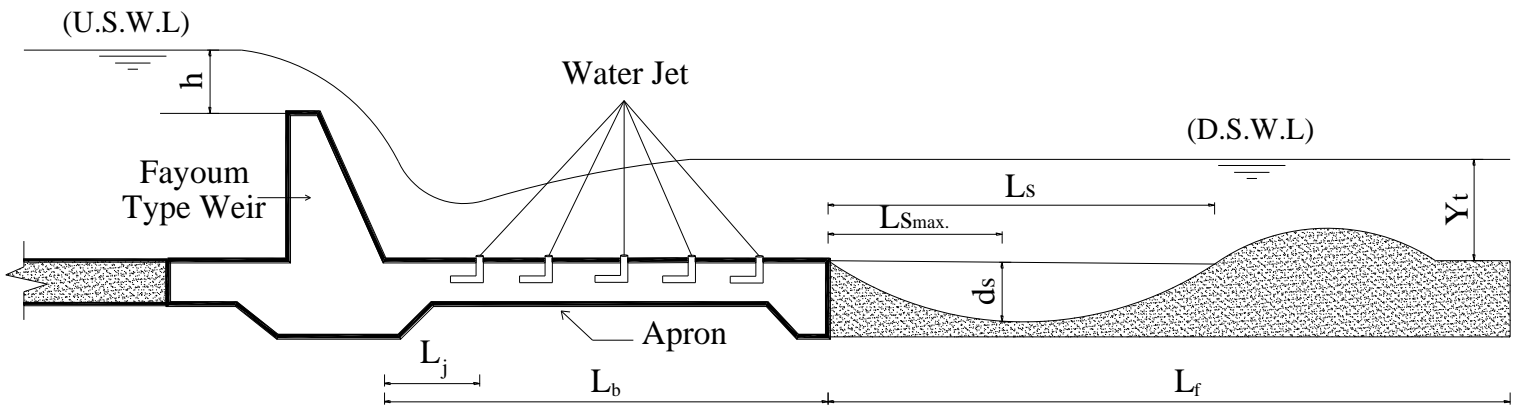

Figure 1 Definition Sketch of the Experimental Setup

The model structure was made from plexiglass material in steel frame walled flume of $26.0 \mathrm{~m}$ long, $1.0 \mathrm{~m}$ wide, and $1.2 \mathrm{~m}$ deep. The glass panels allowed visual investigation of the flow patterns and bed topography. A Fayoum type weir was made of galvanized steel sheet with thickness of $2.0 \mathrm{~mm}$. The dimensions of the weir were $0.5 \mathrm{~m}$ high, $0.1 \mathrm{~m}$ crest width, $1.0 \mathrm{~m}$ crest length and 1:2 slope for downstream side. The stilling basin length was $3.6 \mathrm{~m}(0.85 \mathrm{~m}$ upstream the weir, $0.35 \mathrm{~m}$ under the weir and $2.4 \mathrm{~m}$ downstream the weir toe), as illustrated in Figure 2.

The movable bed material length was $5.0 \mathrm{~m}$ with $0.3 \mathrm{~m}$ thickness, and it was located just downstream the solid apron. Two bed materials were used for all model tests, as shown in Table 1, which were medium sand and fine gravel, [19]. The values of geometric mean diameter $\mathrm{d}_{50}$ of both materials were $0.423 \mathrm{~mm}$ and $1.397 \mathrm{~mm}$ respectively. It should be mentioned that bed materials were analyzed in the sedimentation laboratory at HRI.
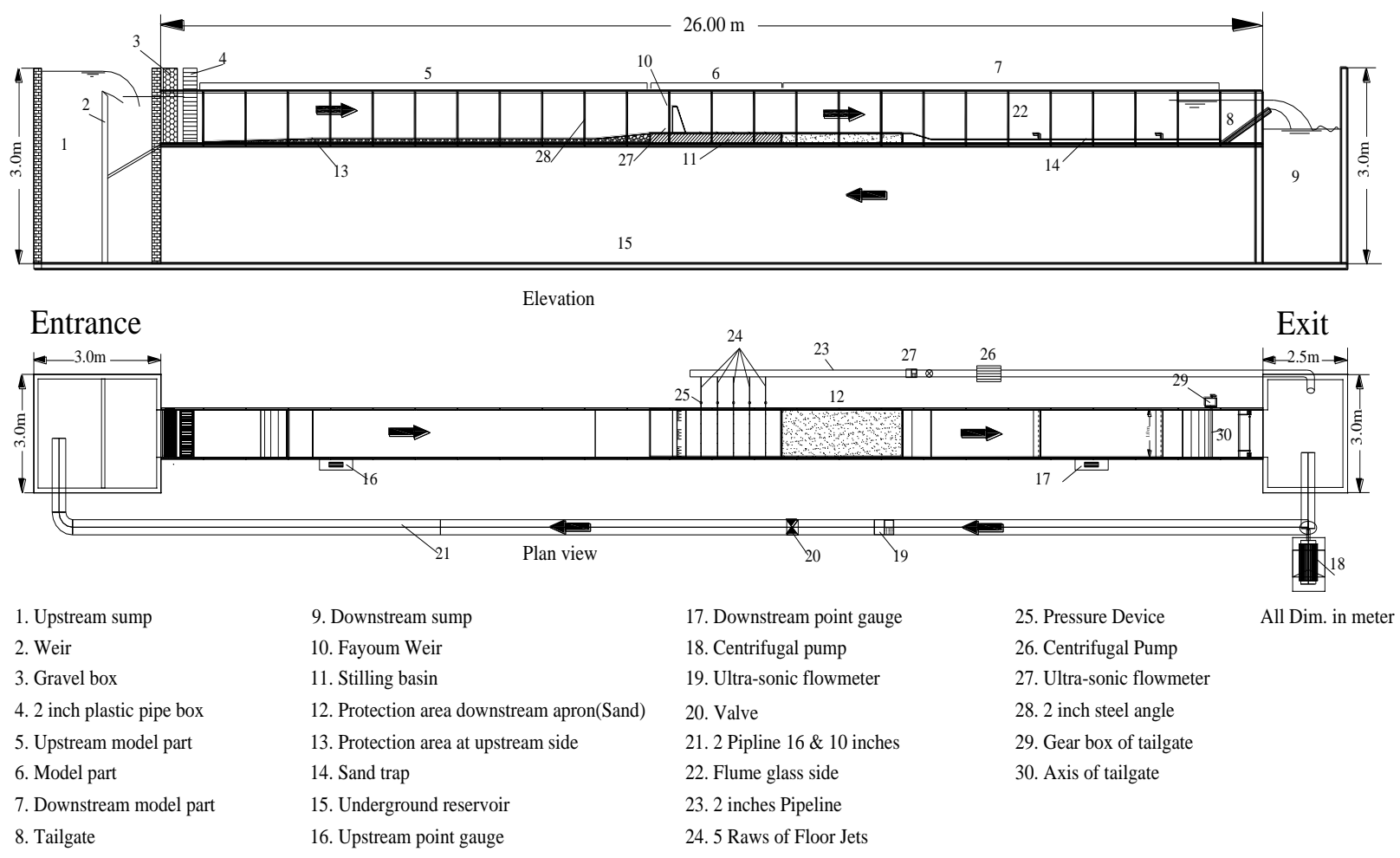

Figure 2 Details of the Flume and Model Arrangement 
Table 1 Summary of Characteristics of Two Bed Materials

\begin{tabular}{|c|c|c|}
\hline \multirow{2}{*}{$\begin{array}{c}\text { Material } \\
\text { Characteristics }\end{array}$} & \multicolumn{2}{|c|}{ Particle Size, $\mathbf{~ m m}$} \\
\cline { 2 - 3 } & Medium Sand & Fine Gravel \\
\hline $\mathbf{d}_{\mathbf{1 5}}$ & 0.221 & 0.939 \\
\hline $\mathbf{d}_{\mathbf{5 0}}$ & 0.423 & 1.397 \\
\hline $\mathbf{d}_{\mathbf{8 5}}$ & 0.759 & 2.052 \\
\hline $\mathbf{d}_{\mathbf{8 4}} / \mathbf{d}_{\mathbf{5 0}}$ & 1.793 & 1.469 \\
\hline $\mathbf{d}_{\mathbf{5 0}} / \mathbf{d}_{\mathbf{1 6}}$ & 1.918 & 1.488 \\
\hline
\end{tabular}

\section{MODEL RUNS}

Forty-five experimental runs were carried out for simulating nine flow conditions of three flow discharges $(\mathrm{Q}=120,150$ and $180 \mathrm{~L} / \mathrm{s})$ and three tail water depths $\left(\mathrm{y}_{\mathrm{t}}=20,25\right.$ and $\left.30 \mathrm{~cm}\right)$ using five different designs of stilling basin according to arrangement of floor jet rows, as shown in Table 2. The test runs were operated for each bed material. The experiments were designed to vary the variables of flow discharge, tail water depth and design of floor jets. The scour downstream the apron was measured using mesh with $0.25 \mathrm{~m}$, as shown in Figure 3.

Table 2 Experimental Designs for Test Runs

\begin{tabular}{|c|c|c|c|c|c|}
\hline \multirow{2}{*}{ Design } & \multicolumn{5}{|c|}{ Rows for Floor Jets } \\
\hline & Row No. 1 & Row No. 2 & Row No. 3 & Row No. 4 & Row No. 5 \\
\hline $\mathbf{A}$ & $\mathrm{X}$ & $\mathrm{X}$ & $\mathrm{X}$ & $\mathrm{X}$ & $\mathrm{X}$ \\
\hline B & $\sqrt{ }$ & $\sqrt{ }$ & $\sqrt{ }$ & $\sqrt{ }$ & $\sqrt{ }$ \\
\hline $\mathbf{C}$ & $\sqrt{ }$ & $\sqrt{ }$ & $\sqrt{ }$ & $\mathrm{X}$ & $\mathrm{X}$ \\
\hline $\mathbf{D}$ & $\mathrm{X}$ & $\mathrm{X}$ & $\sqrt{ }$ & $\sqrt{ }$ & $\sqrt{ }$ \\
\hline $\mathbf{E}$ & $\sqrt{ }$ & $\mathrm{X}$ & $\sqrt{ }$ & $\mathrm{X}$ & $\sqrt{ }$ \\
\hline \multicolumn{6}{|c|}{$\sqrt{ }$ : Opened } \\
\hline \multicolumn{6}{|c|}{ X: Closed } \\
\hline
\end{tabular}

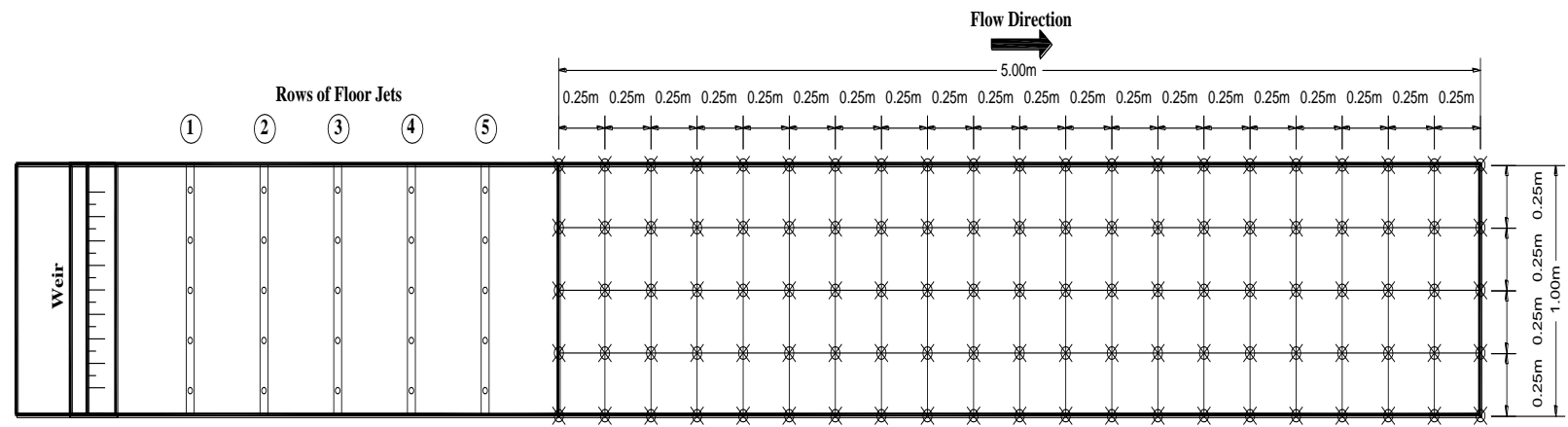

Figure 3 Locations of Bed Configuration Measuring Points

\section{REULTS AND DISCUSSION}

The bed configurations downstream stilling basin for all various designs of floor jets and for both bed materials at high flow conditions are presented in Table 3. 
Table 3 Bed Configurations Downstream Stilling Basin for Various Designs of Floor Jets

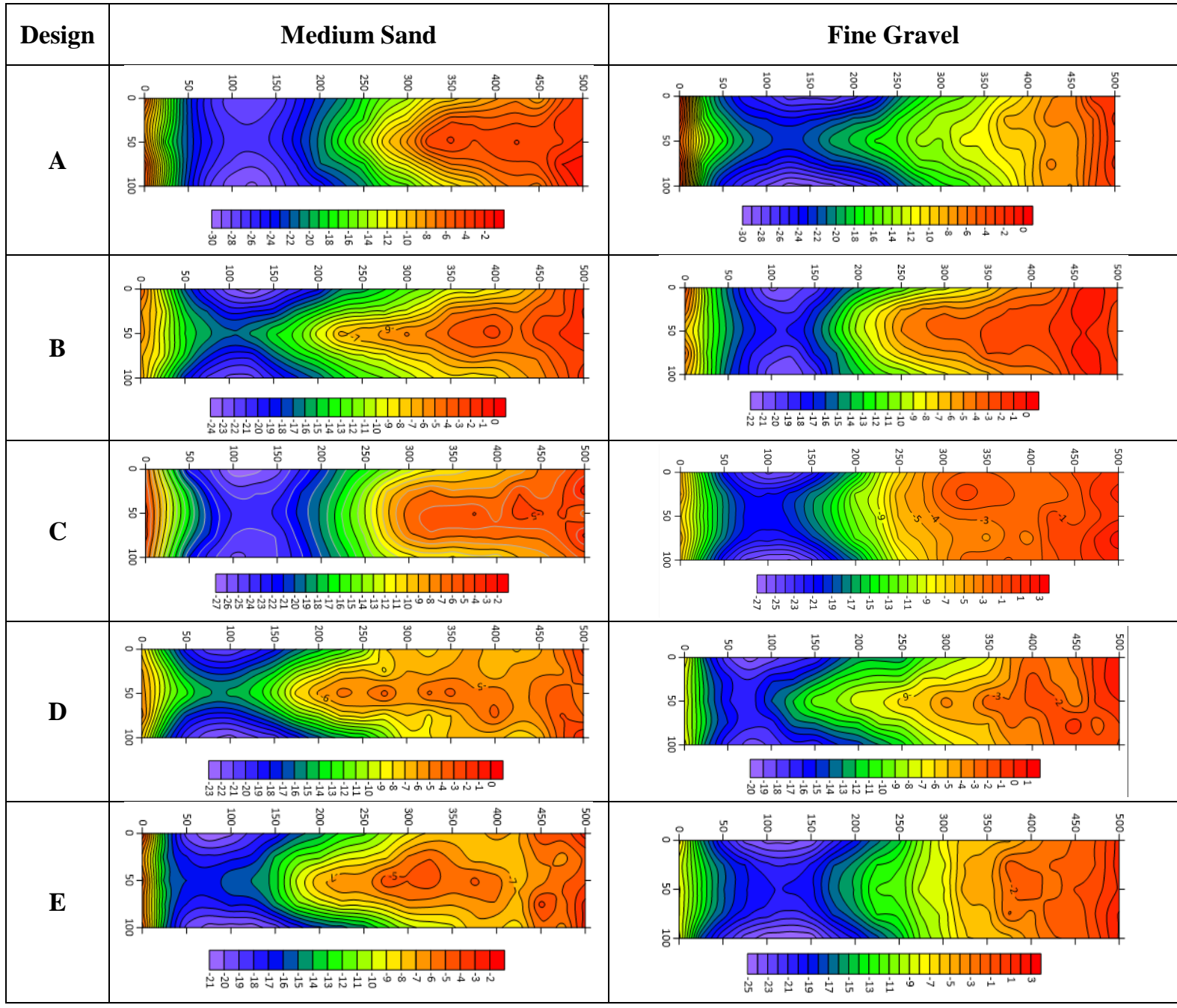

For all various designs of floor jets with different flow discharges and tail water depths, the obtained results of the scour depths are presented in Figures 4, 5, 6, 7 and 8 for the two bed materials of medium sand and fine gravel.

It was found that the maximum scour depths for the two bed materials occurred for design A associated with $\mathrm{Q}=180 \mathrm{~L} / \mathrm{s}$ and $\mathrm{y}_{\mathrm{t}}=20 \mathrm{~cm}$, while the minimum scour depths for the two bed materials happened for design $\mathrm{D}$ associated with $\mathrm{Q}=120 \mathrm{~L} / \mathrm{s}$ and $\mathrm{y}_{\mathrm{t}}=30 \mathrm{~cm}$.

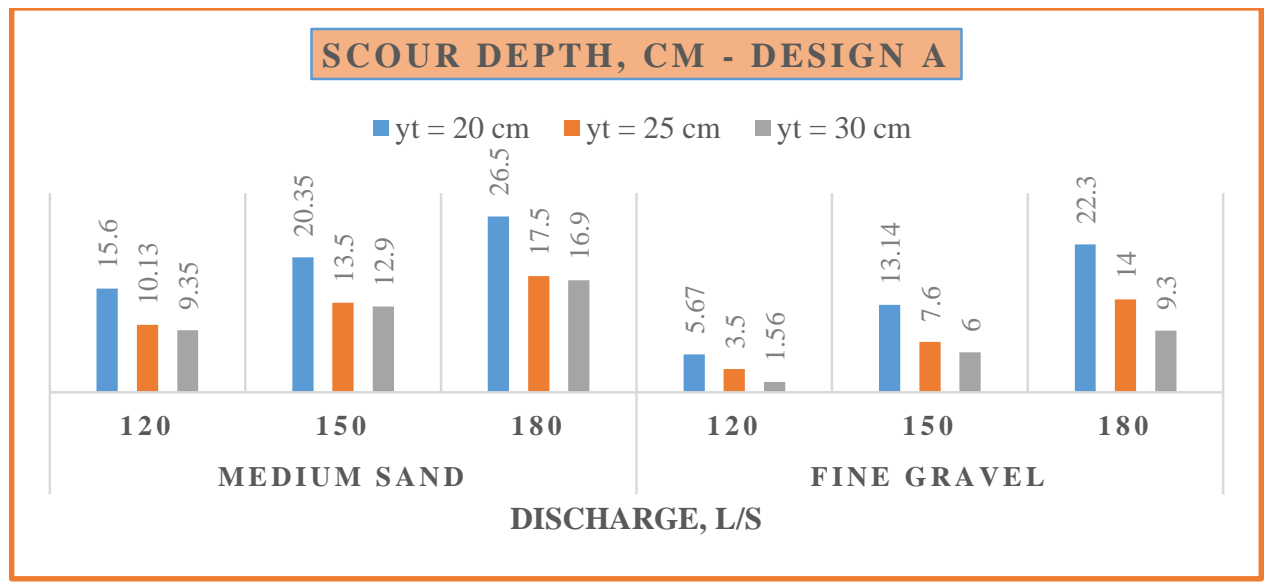

Figure 4 Scour Depth for Design A of Floor Jets with different Discharges, Tail Depths and Bed Materials 


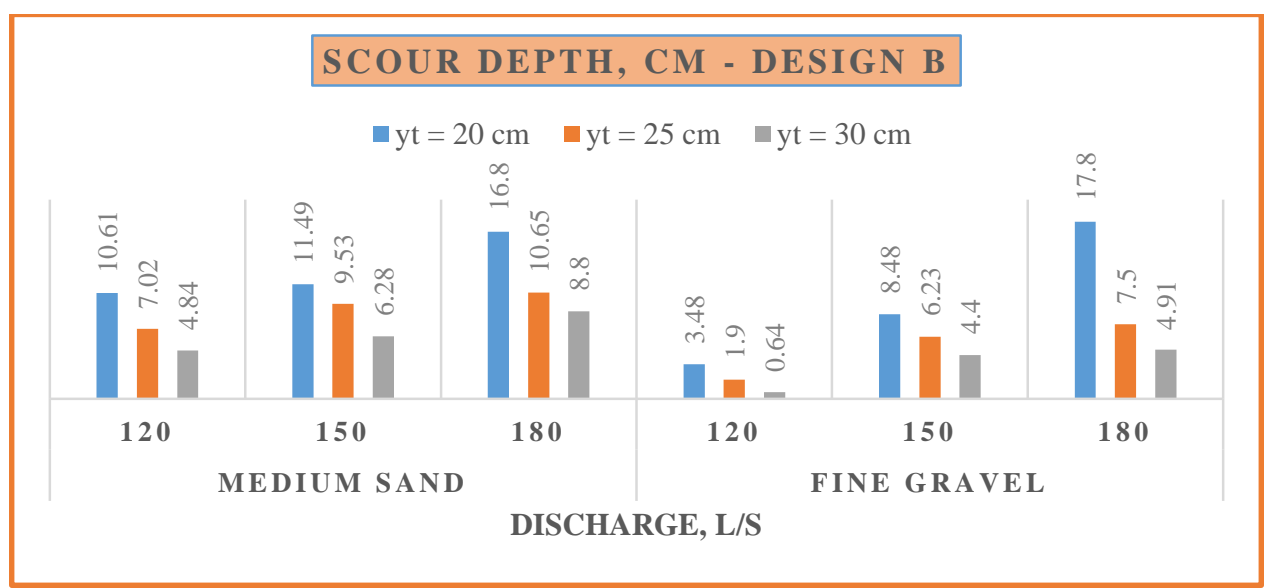

Figure 5 Scour Depth for Design B of Floor Jets with different Discharges, Tail Depths and Bed Materials

For medium sand bed material, it was found that the maximum and minimum scour depths were $26.5 \mathrm{~cm}$ and $2.23 \mathrm{~cm}$, respectively. For fine gravel bed material, it was recorded that the maximum and minimum scour depths were $22.3 \mathrm{~cm}$ and 0.42 $\mathrm{cm}$, respectively.

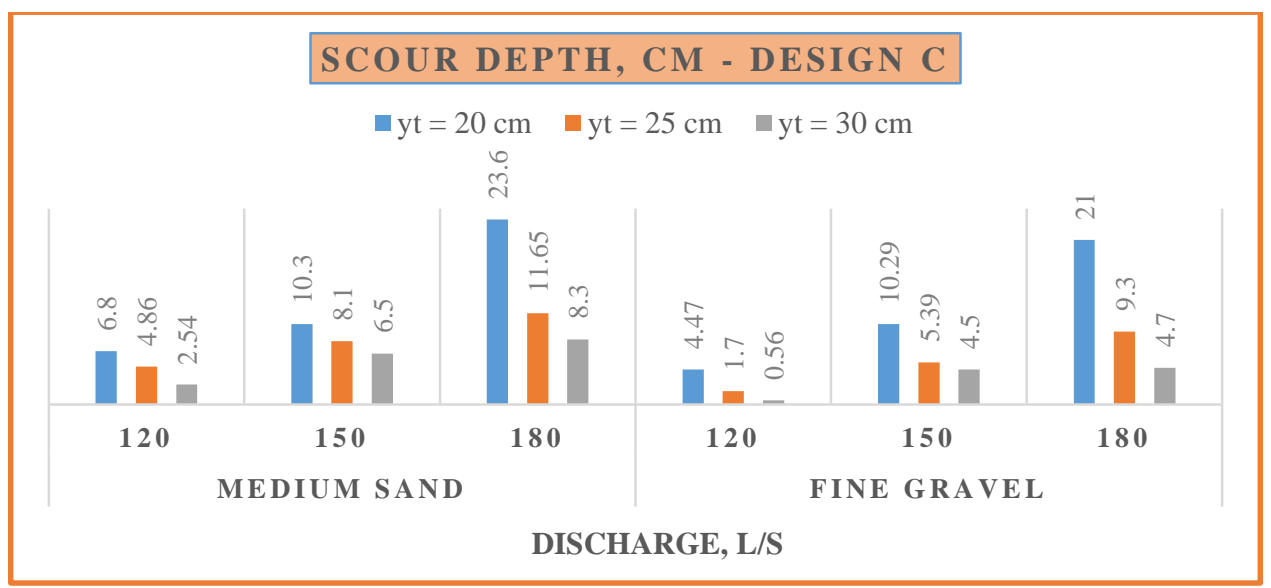

Figure 6 Scour Depth for Design C of Floor Jets with different Discharges, Tail Depths and Bed Materials

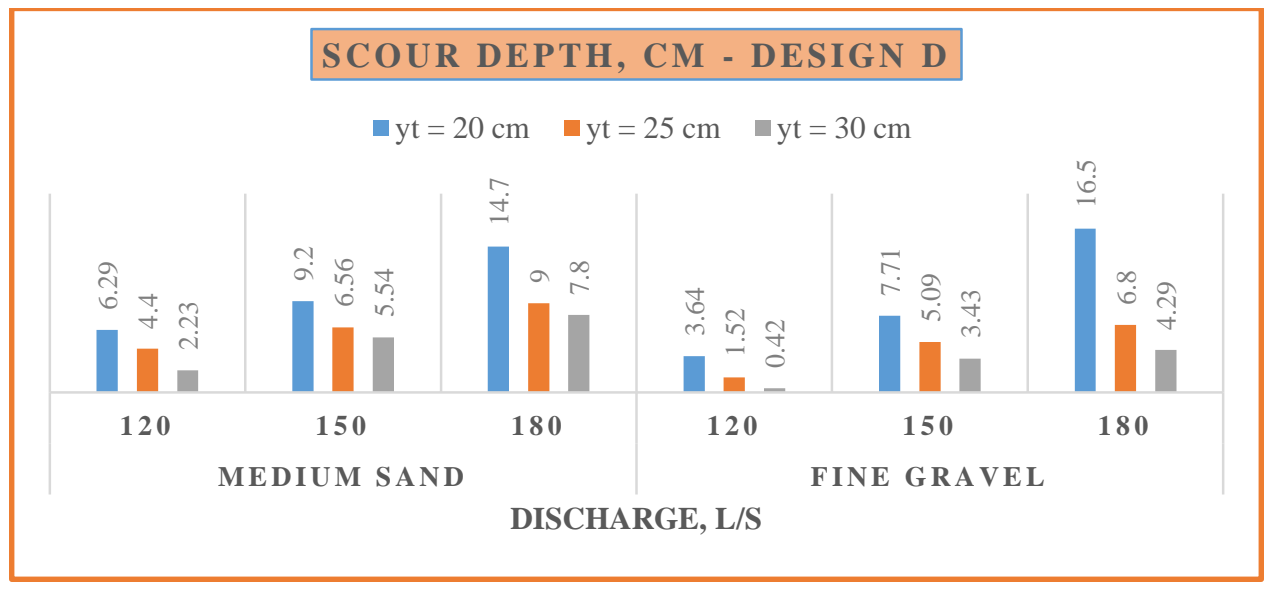

Figure 7 Scour Depth for Design D of Floor Jets with different Discharges, Tail Depths and Bed Materials 


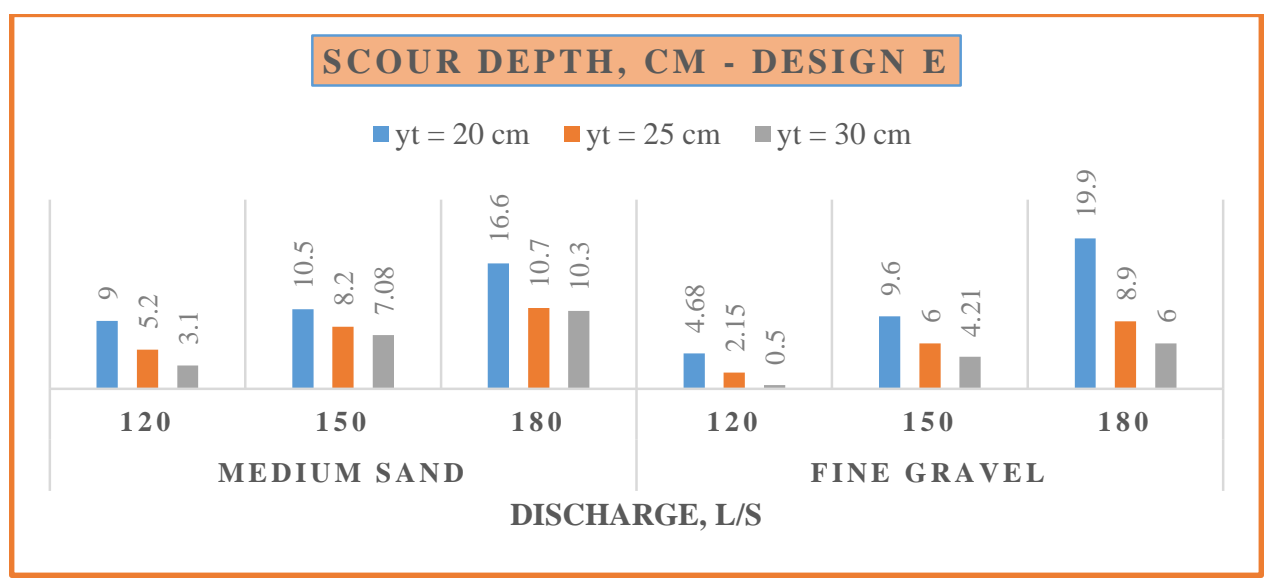

Figure 8 Scour Depth for Design E of Floor Jets with different Discharges, Tail Depths and Bed Materials

For employing fine gravel as a bed material instead of medium sand, the values of reduction percentage in scour depths were calculated and illustrated in Table 4.

Table 4 Reduction Percentage in Scour Depth

\begin{tabular}{|c|c|c|c|c|c|c|}
\hline \multirow{3}{*}{ Q, L/s } & \multirow{2}{*}{ yt, cm } & \multicolumn{5}{|c|}{ Reduction Percentage, \%, for Floor Jets Design } \\
\cline { 2 - 7 } & & $\mathrm{A}$ & $\mathrm{B}$ & $\mathrm{C}$ & $\mathrm{D}$ & $\mathrm{E}$ \\
\hline \multirow{3}{*}{120} & 20 & 63.7 & 67.2 & 34.3 & 42.1 & 48.0 \\
\cline { 2 - 7 } & 25 & 65.4 & 72.9 & 65.0 & 65.5 & 58.7 \\
\cline { 2 - 7 } & 30 & 83.3 & 86.8 & 78.0 & 81.2 & 83.9 \\
\hline \multirow{3}{*}{150} & 20 & 35.4 & 26.2 & 0.1 & 16.2 & 8.6 \\
\cline { 2 - 7 } & 25 & 43.7 & 34.6 & 33.5 & 22.4 & 26.8 \\
\cline { 2 - 7 } & 30 & 53.5 & 29.9 & 30.8 & 38.1 & 40.5 \\
\hline \multirow{3}{*}{180} & 20 & 15.8 & -6.0 & 11.0 & -12.2 & -19.9 \\
\cline { 2 - 7 } & 25 & 20.0 & 29.6 & 20.2 & 24.4 & 16.8 \\
\cline { 2 - 7 } & 30 & 45.0 & 44.2 & 43.4 & 45.0 & 41.7 \\
\hline
\end{tabular}

It could be seen that the reduction in scour depths were more accomplished for design $\mathrm{B}$ with $\mathrm{Q}=120 \mathrm{~L} / \mathrm{s}$ and for design $\mathrm{A}$ with both discharges $\mathrm{Q}=150 \mathrm{~L} / \mathrm{s}$ and $\mathrm{Q}=180 \mathrm{~L} / \mathrm{s}$. Also, it was found that the scour depth increased for designs $\mathrm{B}, \mathrm{D}$ and $\mathrm{E}$ with $\mathrm{Q}=180 \mathrm{~L} / \mathrm{s}, \mathrm{y}_{\mathrm{t}}=20 \mathrm{~cm}$.

For all various designs of floor jets with different flow discharges and tail water depths, the obtained results of the scour lengths are presented in Figures 9, 10, 11, 12 and 13 for the two bed materials of medium sand and fine gravel.

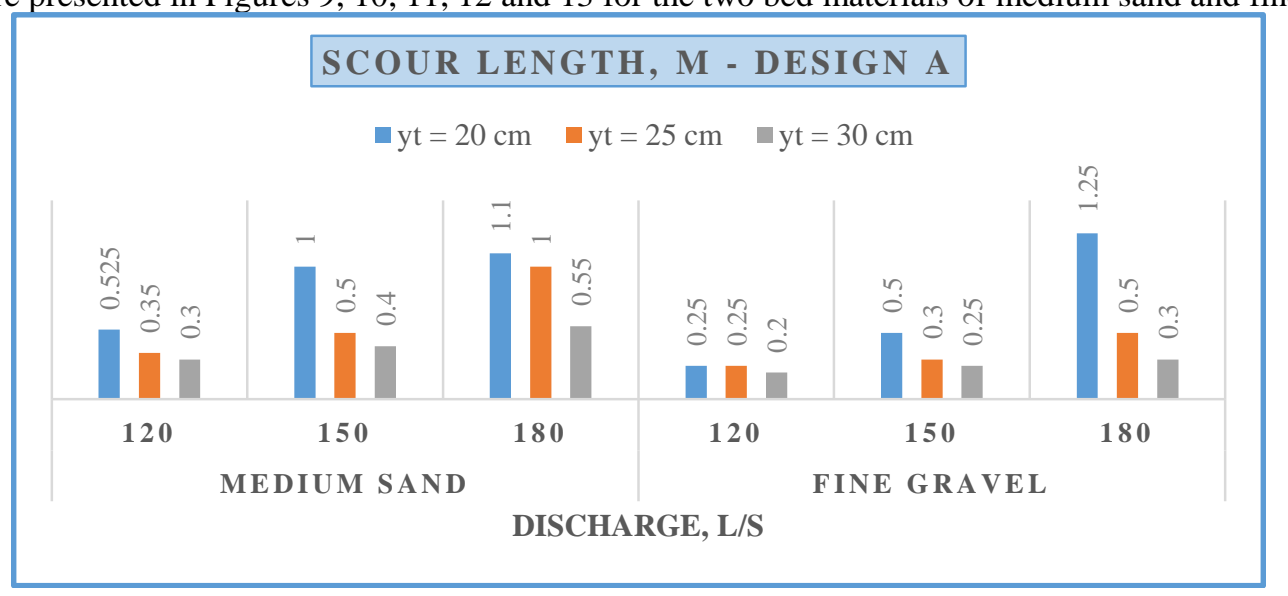

Figure 9 Scour Length for Design A of Floor Jets with different Discharges, Tail Depths and Bed Materials 


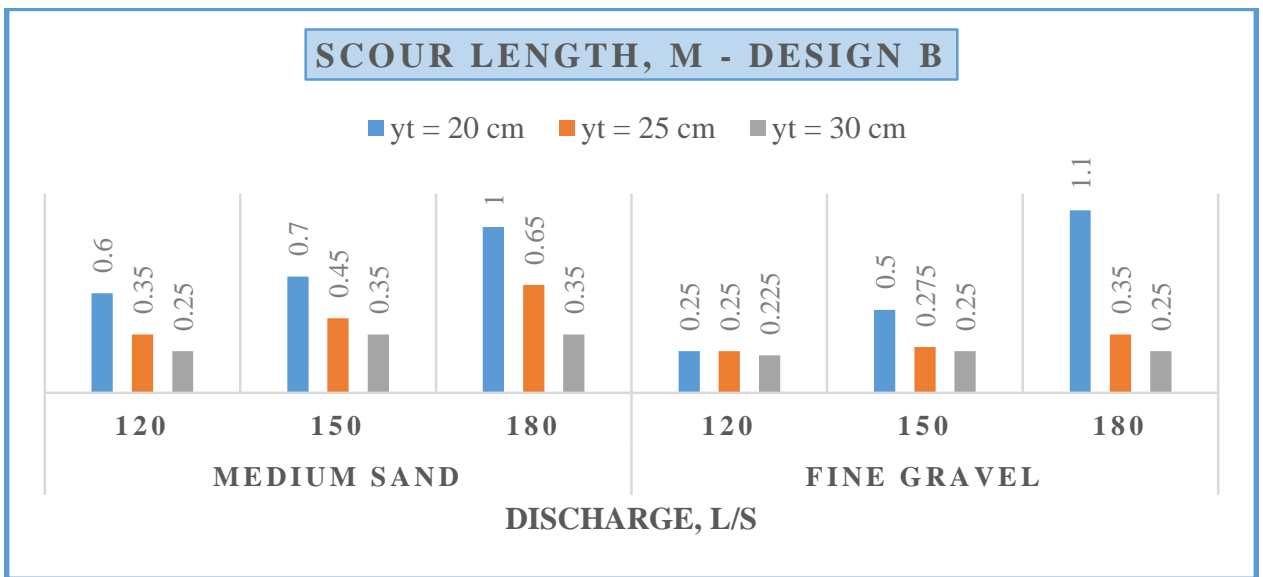

Figure 10 Scour Length for Design B of Floor Jets with different Discharges, Tail Depths and Bed Materials

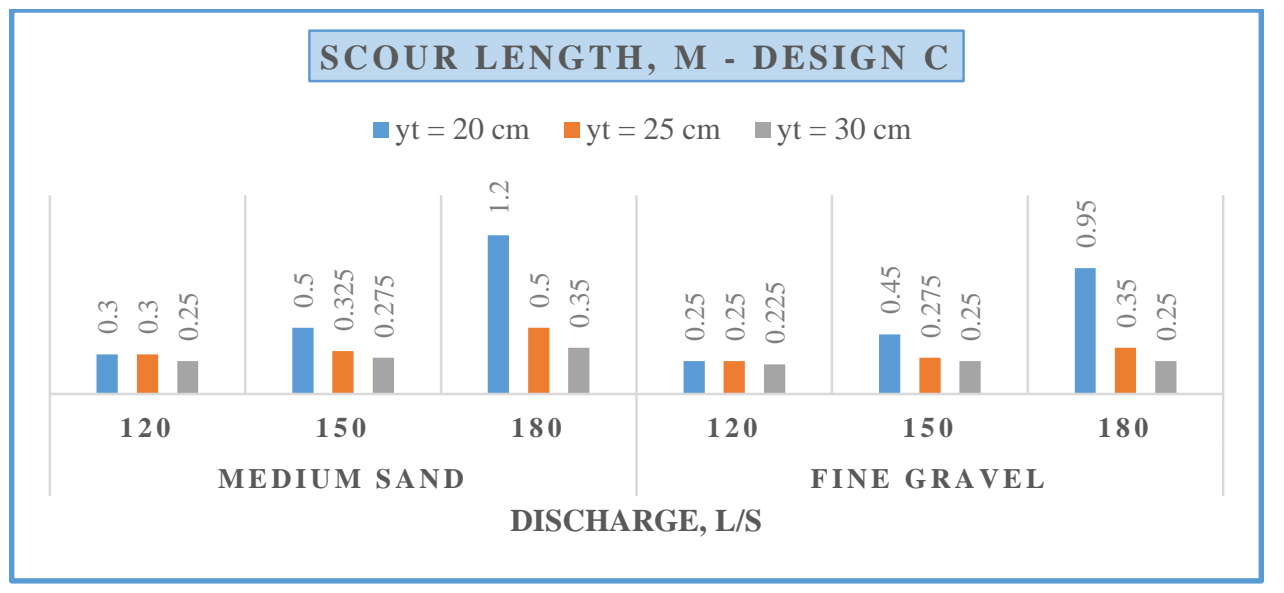

Figure 11 Scour Length for Design C of Floor Jets with different Discharges, Tail Depths and Bed Materials

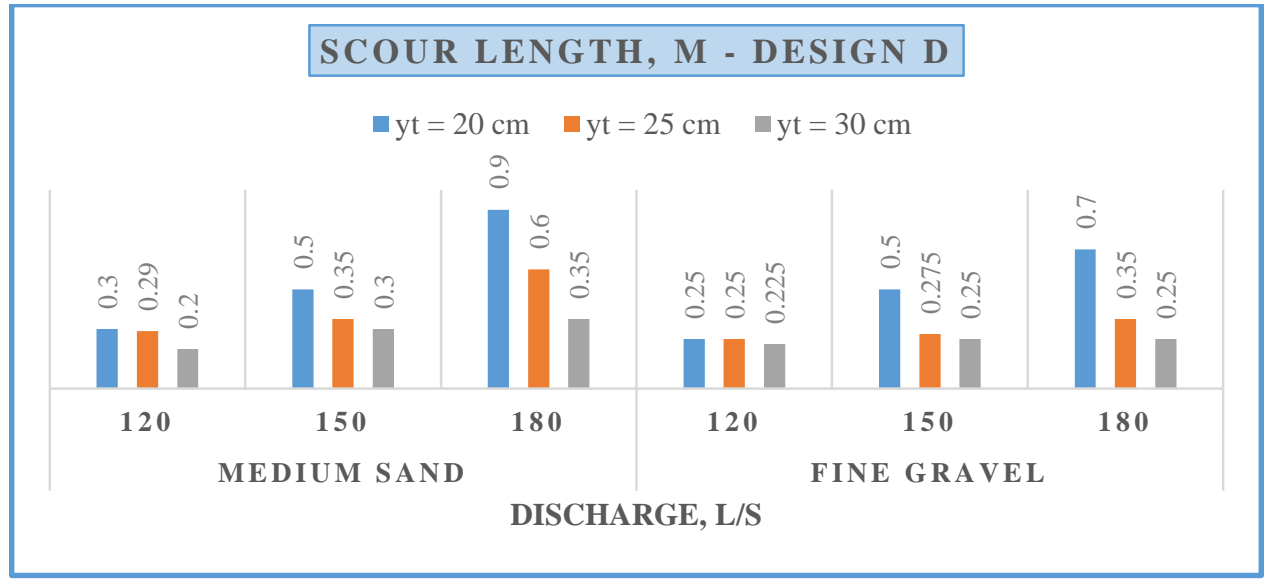

Figure 12 Scour Length for Design D of Floor Jets with different Discharges, Tail Depths and Bed Materials 


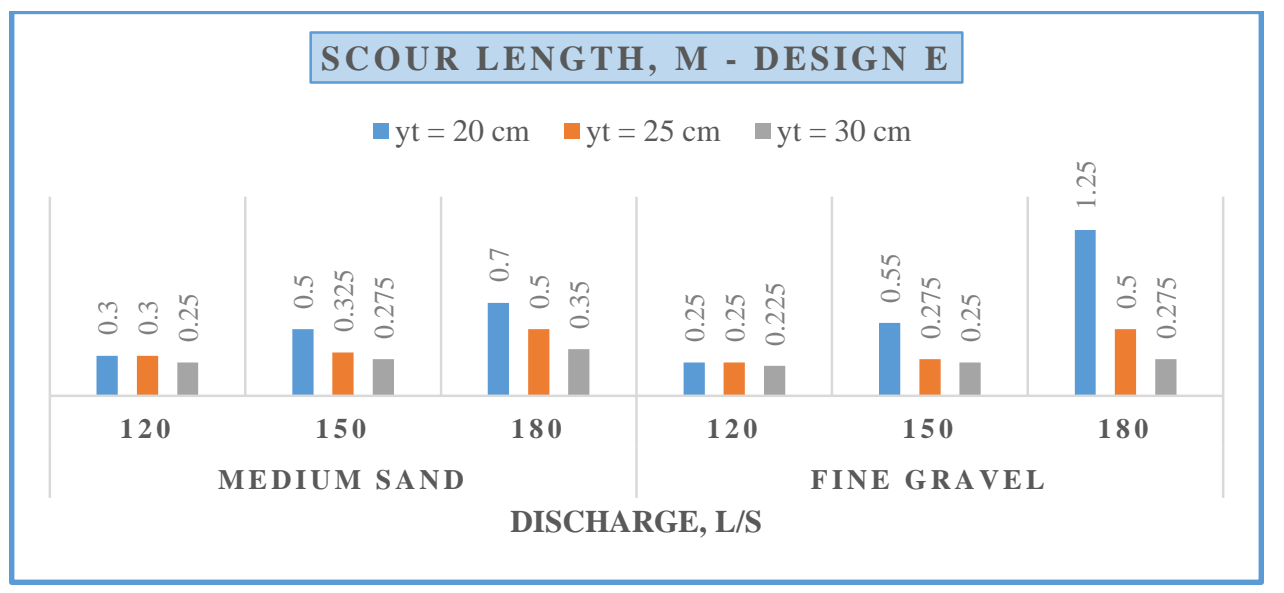

Figure 13 Scour Length for Design E of Floor Jets with different Discharges, Tail Depths and Bed Materials

It was found that the maximum scour length for medium sand bed material occurred for design $\mathrm{C}$ associated with $\mathrm{Q}=180 \mathrm{~L} / \mathrm{s}$ and $y_{t}=20 \mathrm{~cm}$, while the maximum scour length for fine gravel bed material occurred for both designs A and E associated with $\mathrm{Q}=180 \mathrm{~L} / \mathrm{s}$ and $\mathrm{y}_{\mathrm{t}}=20 \mathrm{~cm}$.

The minimum scour length for medium sand bed material happened for design D associated with Q $=120 \mathrm{~L} / \mathrm{s}$ and $\mathrm{y}_{\mathrm{t}}=30 \mathrm{~cm}$, while the minimum scour length for fine gravel bed material occurred for design A associated with $Q=120 \mathrm{~L} / \mathrm{s}$ and $\mathrm{y}_{\mathrm{t}}=30$ $\mathrm{cm}$.

For medium sand bed material, it was found that the maximum and minimum scour lengths were $1.20 \mathrm{~m}$ and $0.20 \mathrm{~m}$, respectively. For fine gravel bed material, it was found that the maximum and minimum scour lengths were $1.25 \mathrm{~m}$ and 0.20 m, respectively.

For employing fine gravel as a bed material instead of medium sand, the values of reduction percentage in scour lengths were calculated and illustrated in Table 5.

It could be seen that the reduction in scour lengths were more accomplished by design B for discharge $Q=120 \mathrm{~L} / \mathrm{s}$ with both tail water depths $\mathrm{y}_{\mathrm{t}}=20 \mathrm{~cm}$ and $\mathrm{y}_{\mathrm{t}}=25 \mathrm{~cm}$, while the reduction in scour length was achieved by design $\mathrm{A}$ for discharge $\mathrm{Q}=$ $120 \mathrm{~L} / \mathrm{s}$ with $\mathrm{y}_{\mathrm{t}}=30 \mathrm{~cm}$. The reduction in scour lengths were obviously accomplished for discharge $\mathrm{Q}=150 \mathrm{~L} / \mathrm{s}$ by design $\mathrm{B}$, and for discharge $\mathrm{Q}=180 \mathrm{~L} / \mathrm{s}$ by design $\mathrm{D}$.

Table 5 Reduction Percentage in Scour Length

\begin{tabular}{|c|c|c|c|c|c|c|}
\hline \multirow{2}{*}{ Q, L/s } & \multirow{2}{*}{$\mathbf{y}_{\mathbf{t}} \mathbf{~ c m}$} & \multicolumn{5}{|c|}{ Reduction Percentage, \%, for Floor Jets Design } \\
\cline { 3 - 7 } & & $\mathbf{A}$ & $\mathbf{B}$ & $\mathbf{C}$ & $\mathbf{D}$ & $\mathbf{E}$ \\
\hline \multirow{3}{*}{$\mathbf{1 2 0}$} & $\mathbf{2 0}$ & 52.4 & 58.3 & 16.7 & 16.7 & 16.7 \\
\cline { 2 - 7 } & $\mathbf{2 5}$ & 28.6 & 28.6 & 16.7 & 13.8 & 16.7 \\
\cline { 2 - 7 } & $\mathbf{3 0}$ & 33.3 & 10.0 & 10.0 & -12.5 & 10.0 \\
\hline \multirow{3}{*}{$\mathbf{1 5 0}$} & $\mathbf{2 0}$ & 50.0 & 28.6 & 10.0 & 0.0 & -10.0 \\
\cline { 2 - 7 } & $\mathbf{2 5}$ & 40.0 & 38.9 & 15.4 & 21.4 & 15.4 \\
\cline { 2 - 7 } & $\mathbf{3 0}$ & 37.5 & 28.6 & 9.1 & 16.7 & 9.1 \\
\hline \multirow{3}{*}{$\mathbf{1 8 0}$} & $\mathbf{2 0}$ & -13.6 & -10.0 & 20.8 & 22.2 & -78.6 \\
\cline { 2 - 7 } & $\mathbf{2 5}$ & 50.0 & 46.2 & 30.0 & 41.7 & 0.0 \\
\cline { 2 - 7 } & $\mathbf{3 0}$ & 45.5 & 28.6 & 28.6 & 28.6 & 21.4 \\
\hline
\end{tabular}

It was found that the scour lengths increased for discharge $Q=180 \mathrm{~L} / \mathrm{s}$ with $\mathrm{y}_{\mathrm{t}}=20 \mathrm{~cm}$ for designs A, B and E. Also, the scour lengths increased for discharge $Q=120 \mathrm{~L} / \mathrm{s}$ with $\mathrm{y}_{\mathrm{t}}=30 \mathrm{~cm}$ for design $\mathrm{D}$, and for discharge $\mathrm{Q}=150 \mathrm{~L} / \mathrm{s} \mathrm{with} \mathrm{y}_{\mathrm{t}}=20 \mathrm{~cm}$ for design E.

It was clearly noticed that there was no impact of changing the bed material for flow condition $\quad Q=150 \mathrm{~L} / \mathrm{s}, \mathrm{yt}=20 \mathrm{~cm}$ for case $\mathrm{D}$ and for flow condition $\mathrm{Q}=180 \mathrm{~L} / \mathrm{s}, \mathrm{yt}=25 \mathrm{~cm}$ for case $\mathrm{E}$. 
For all various designs of floor jets with different flow discharges and tail water depths, the obtained results of the scour volumes are presented in Figures 14, 15, 16, 17 and 18 for the two bed materials of medium sand and fine gravel.

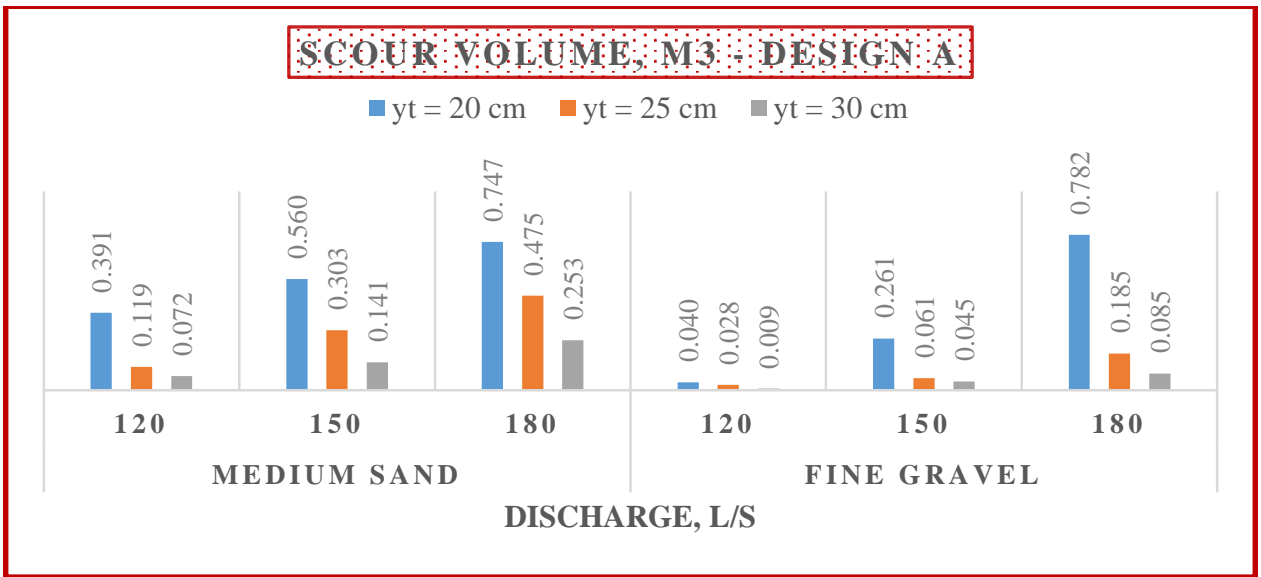

Figure 14 Scour Volume for Design A of Floor Jets with different Discharges, Tail Depths and Bed Materials

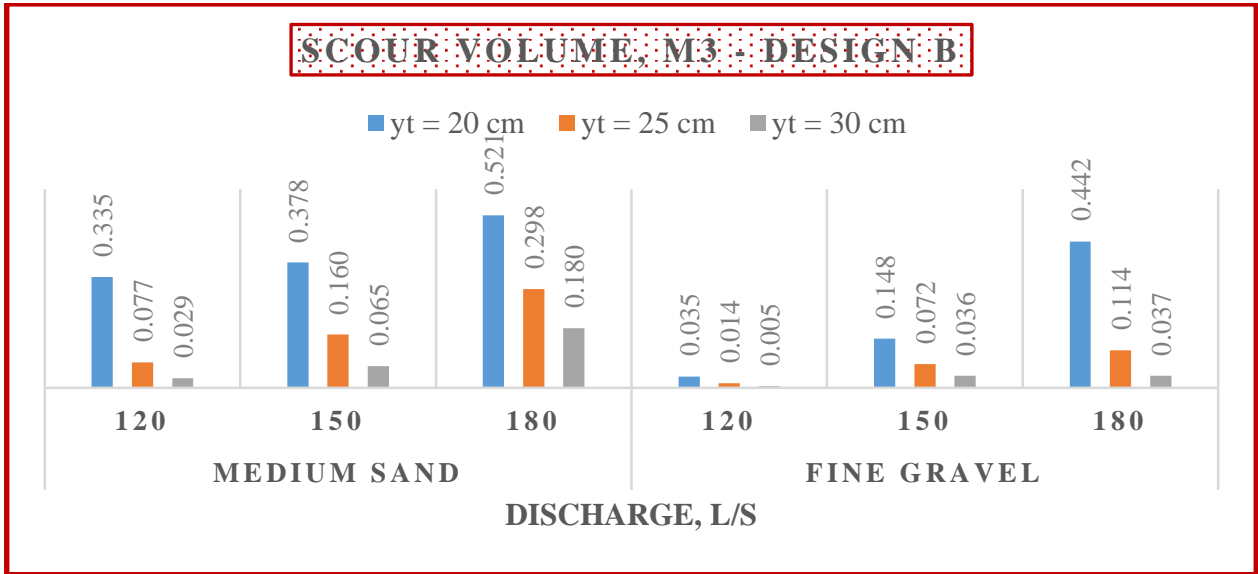

Figure 15 Scour Volume for Design B of Floor Jets with different Discharges, Tail Depths and Bed Materials

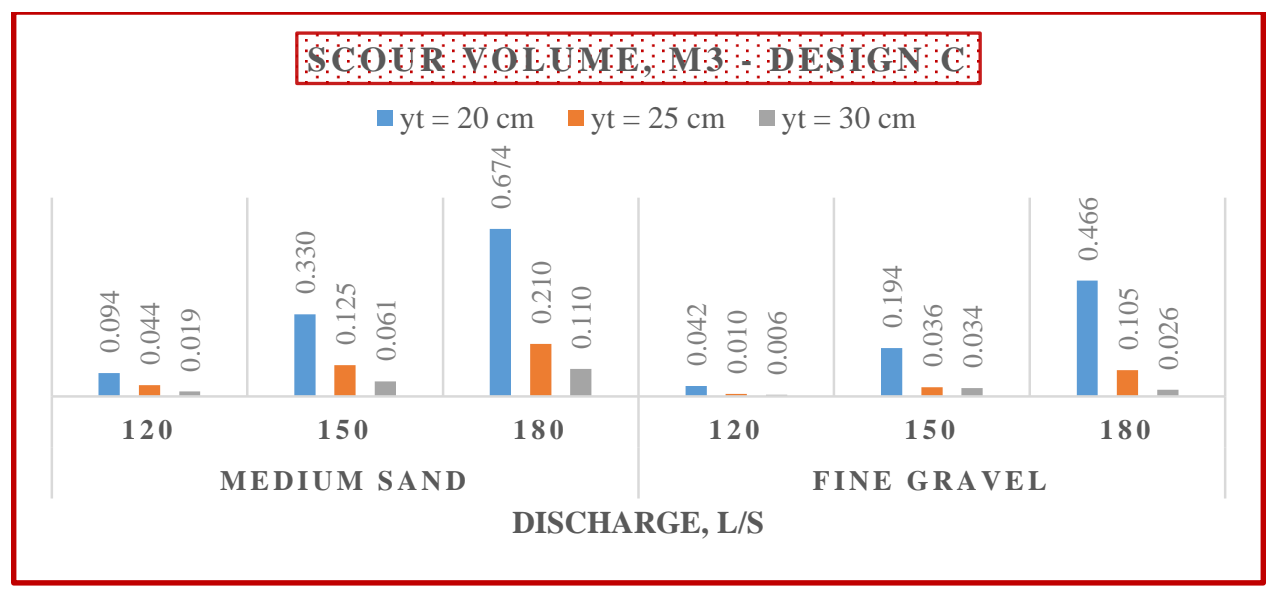

Figure 16 Scour Volume for Design C of Floor Jets with different Discharges, Tail Depths and Bed Materials 


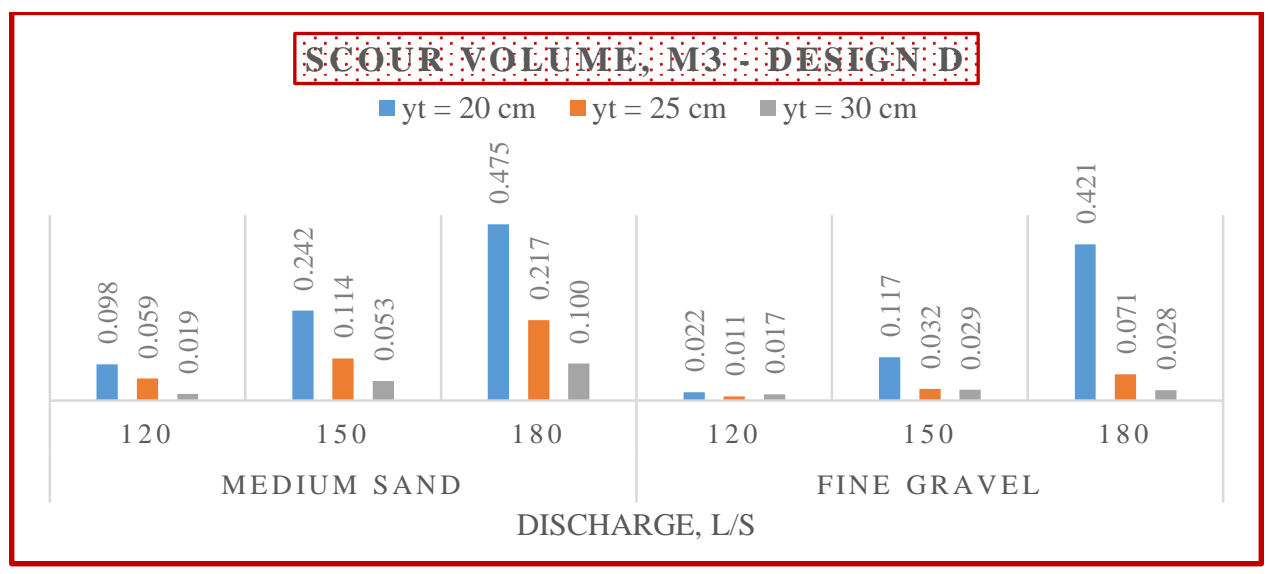

Figure 17 Scour Volume for Design D of Floor Jets with different Discharges, Tail Depths and Bed Materials

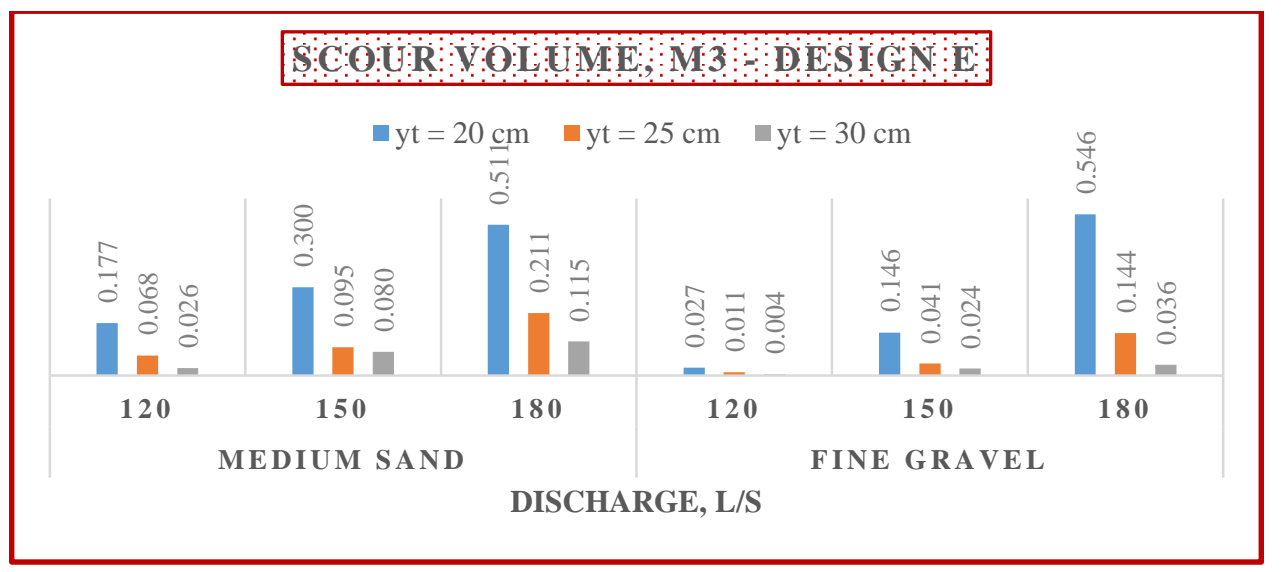

Figure 18 Scour Volume for Design E of Floor Jets with different Discharges, Tail Depths and Bed Materials

It was found that the maximum scour volumes for the two bed materials occurred for design A associated with $\mathrm{Q}=180 \mathrm{~L} / \mathrm{s}$ and $\mathrm{y}_{\mathrm{t}}=20 \mathrm{~cm}$. The minimum scour volumes for medium sand bed material happened for both designs C and D associated with Q $=120 \mathrm{~L} / \mathrm{s}$ and $\mathrm{y}_{\mathrm{t}}=30 \mathrm{~cm}$, while the minimum scour volume for fine gravel bed material occurred for design E associated with $\mathrm{Q}=120 \mathrm{~L} / \mathrm{s}$ and $\mathrm{y}_{\mathrm{t}}=30 \mathrm{~cm}$.

For medium sand bed material, it was recorded that the maximum and minimum scour volumes were $0.747 \mathrm{~m}^{3}$ and $0.019 \mathrm{~m}^{3}$, respectively. For fine gravel bed material, it was found that the maximum and minimum scour volumes were $0.782 \mathrm{~m}^{3}$ and $0.004 \mathrm{~m}^{3}$, respectively.

For employing fine gravel as a bed material instead of medium sand, the values of reduction percentage in scour volumes were calculated and illustrated in Table 6.

Table 6 Reduction Percentage in Scour Volume

\begin{tabular}{|c|c|c|c|c|c|c|}
\hline Q, L/s & yt, cm & Design A & Design B & Design C & Design D & Design E \\
\hline \multirow{4}{*}{120} & 20 & 89.8 & 89.7 & 55.7 & 77.1 & 84.8 \\
\cline { 2 - 7 } & 25 & 76.1 & 82.1 & 76.6 & 80.7 & 83.9 \\
\cline { 2 - 7 } & 30 & 88.0 & 83.2 & 67.2 & 9.7 & 83.0 \\
\hline \multirow{4}{*}{150} & 20 & 53.4 & 60.8 & 41.2 & 51.6 & 51.3 \\
\cline { 2 - 7 } & 25 & 79.9 & 55.3 & 71.3 & 72.0 & 57.0 \\
\cline { 2 - 7 } & 30 & 68.4 & 44.2 & 43.9 & 45.2 & 70.2 \\
\hline \multirow{3}{*}{180} & 20 & -4.7 & 15.1 & 30.9 & 11.4 & -7.0 \\
\cline { 2 - 7 } & 25 & 61.0 & 61.9 & 50.2 & 67.2 & 31.9 \\
\cline { 2 - 7 } & 30 & 66.2 & 79.4 & 76.4 & 72.0 & 68.3 \\
\hline
\end{tabular}


It could be seen for discharge $\mathrm{Q}=120 \mathrm{~L} / \mathrm{s}$ that the reduction in scour volumes were more accomplished by design $\mathrm{A}$ for both tail water depths $\mathrm{y}_{\mathrm{t}}=20 \mathrm{~cm}$ and $\mathrm{y}_{\mathrm{t}}=30 \mathrm{~cm}$, and by design $\mathrm{E}$ for $\mathrm{y}_{\mathrm{t}}=25 \mathrm{~cm}$.

For discharge $\mathrm{Q}=150 \mathrm{~L} / \mathrm{s}$, the reduction in scour volumes were more achieved by design $\mathrm{B}$ for tail water depth $\mathrm{y}_{\mathrm{t}}=20 \mathrm{~cm}$, by design A for $\mathrm{y}_{\mathrm{t}}=25 \mathrm{~cm}$, and by design $\mathrm{E}$ for $\mathrm{y}_{\mathrm{t}}=30 \mathrm{~cm}$.

For discharge $\mathrm{Q}=180 \mathrm{~L} / \mathrm{s}$, the reduction in scour volumes were more accomplished by design $\mathrm{C}$ for tail water depth $\mathrm{y}_{\mathrm{t}}=20$ $\mathrm{cm}$, by design $\mathrm{D}$ for $\mathrm{y}_{\mathrm{t}}=25 \mathrm{~cm}$, and by design $\mathrm{B}$ for $\mathrm{y}_{\mathrm{t}}=30 \mathrm{~cm}$.

It was found that the scour volumes increased only for discharge $\mathrm{Q}=180 \mathrm{~L} / \mathrm{s}$ with $\mathrm{y}_{\mathrm{t}}=20 \mathrm{~cm}$ for both designs A and E.

\section{Conclusions}

Based on the experimental model to study the influence of bed material size used downstream stilling basin.

- Using fine gravel bed material improves the bed configurations presented in terms of scour depth and length, where the conclusion may be summarized as follows:

\subsection{Scour depth}

- For the two bed materials, the maximum scour depths occurred by design A for $\mathrm{Q}=180 \mathrm{~L} / \mathrm{s}$ and $\mathrm{y}_{\mathrm{t}}=20 \mathrm{~cm}$, while the minimum scour depths were recorded by design $\mathrm{D}$ for $\mathrm{Q}=120 \mathrm{~L} / \mathrm{s}$ and $\mathrm{y}_{\mathrm{t}}=30 \mathrm{~cm}$.

- For employing fine gravel as a bed material instead of medium sand, reduction in scour depths were more accomplished for $\mathrm{Q}=120 \mathrm{~L} / \mathrm{s}$ by design $\mathrm{B}$, and for both $\mathrm{Q}=150 \mathrm{~L} / \mathrm{s}$ and $\mathrm{Q}=180 \mathrm{~L} / \mathrm{s}$ by design $\mathrm{A}$. The maximum reduction percentage of the scour depth was $86.8 \%$.

- The scour depth increased for $\mathrm{Q}=180 \mathrm{~L} / \mathrm{s}$ with $\mathrm{y}_{\mathrm{t}}=20 \mathrm{~cm}$ by designs $\mathrm{B}, \mathrm{D}$ and $\mathrm{E}$.

\subsection{Scour Length}

- The maximum scour length occurred for $\mathrm{Q}=180 \mathrm{~L} / \mathrm{s}$ and $\mathrm{y}_{\mathrm{t}}=20 \mathrm{~cm}$ by design $\mathrm{C}$ for medium sand bed material, and by designs $\mathrm{A}$ and $\mathrm{E}$ for fine gravel bed material.

- The minimum scour length happened for $\mathrm{Q}=120 \mathrm{~L} / \mathrm{s}$ and $\mathrm{y}_{\mathrm{t}}=30 \mathrm{~cm}$ by design $\mathrm{D}$ for medium sand bed material, and by design A for fine gravel bed material.

- For employing fine gravel as a bed material instead of medium sand, reduction in scour lengths were more accomplished for $\mathrm{Q}=120 \mathrm{~L} / \mathrm{s}$ by design $\mathrm{B}$ for $\mathrm{y}_{\mathrm{t}}=20 \mathrm{~cm}$ and $\mathrm{y}_{\mathrm{t}}=25 \mathrm{~cm}$, and by design A for $\mathrm{y}_{\mathrm{t}}=30 \mathrm{~cm}$. Also, the reduction in scour lengths were more achieved for discharge $\mathrm{Q}=150 \mathrm{~L} / \mathrm{s}$ by design $\mathrm{B}$, and for discharge $\mathrm{Q}=180 \mathrm{~L} / \mathrm{s}$ by design $\mathrm{D}$. The maximum reduction percentage of the scour length was $53.3 \%$.

- The scour lengths increased for discharge $\mathrm{Q}=120 \mathrm{~L} / \mathrm{s}$ with $\mathrm{y}_{\mathrm{t}}=30 \mathrm{~cm}$ by design $\mathrm{D}$, for $\mathrm{Q}=150 \mathrm{~L} / \mathrm{s}$ with $\mathrm{y}_{\mathrm{t}}=20 \mathrm{~cm}$ by design $\mathrm{E}$, and for $\mathrm{Q}=180 \mathrm{~L} / \mathrm{s}$ with $\mathrm{y}_{\mathrm{t}}=20 \mathrm{~cm}$ by designs $\mathrm{A}, \mathrm{B}$ and $\mathrm{E}$.

\subsection{Scour Volume}

- The maximum scour volumes occurred for $\mathrm{Q}=180 \mathrm{~L} / \mathrm{s}$ and $\mathrm{y}_{\mathrm{t}}=20 \mathrm{~cm}$ by design $\mathrm{A}$ for the two bed materials.

- The minimum scour volumes happened for $\mathrm{Q}=120 \mathrm{~L} / \mathrm{s}$ and $\mathrm{y}_{\mathrm{t}}=30 \mathrm{~cm}$ by both designs $\mathrm{C}$ and $\mathrm{D}$ for medium sand bed material, and for $\mathrm{Q}=120 \mathrm{~L} / \mathrm{s}$ and $\mathrm{y}_{\mathrm{t}}=30 \mathrm{~cm}$ by design $\mathrm{E}$ for fine gravel bed.

- The scour volumes increased only for discharge $\mathrm{Q}=180 \mathrm{~L} / \mathrm{s}$ with $\mathrm{y}_{\mathrm{t}}=20 \mathrm{~cm}$ by the two designs $\mathrm{A}$ and $\mathrm{E}$.

\section{Acknowledgments}

This research is a part of $\mathrm{Ph}$. D thesis of the last author under supervision of the other authors. All authors are appreciatively acknowledging the Hydraulics Research Institute (HRI), National Water Research Center (NWRC), Ministry of Water Resources and Irrigation (MWRI), Egypt for collaboration and facilitating the physical modeling.

\section{References}

[1] Edward AE. (1959): "Hydraulic energy dissipators". New York, Toronto, London: Mc-Graw Hill Book Co., Inc.

[2] Peterka AJ. (1978): "Hydraulic design of stilling basin and energy dissipators". Washington, DC: U.S. Dept. of the Interior Bureau of Reclamation.

[3] Yasser A. Moussa, Abdel-Azim M. Ali and Yasser K. Saleh (2018): "Performance of sills over aprons under the eff ect of submerged hydraulic jump, (case study: Naga Hammadi Barrage)", Ain Shams Engineering Journal, Vol. 9, Issue 4, Dec., pp. $1365-1374$.

[4] Ahmed Mostafa Ahmed Amin (2015): "Physical model study for mitigating local scour downstream of clear over-fall weirs", Ain Shams Engineering Journal, vol. 6, issue 4, Dec., pp. 1143-1150.

[5] Akhmad Adi Sulianto and Keisuke Murakami (2015): "Study on Local Scouring of Gravel Mound due to Tsunami Overflow", Procedia Engineering, vol. 116, pp. 195-202. 
[6] Xiao-xie LIU and Yee-Meng CHIEW (2014): "Effect of upward seepage on bedload transport rate", Journal of Water Science and Engineering, Vol. 7, Issue 2, April, pp. 208-217.

[7] Esam El-Deen Yousry El-Azab Helal (2014): "Minimizing scour downstream of hydraulic structures using single line of floor water jets", Ain Shams Engineering Journal, Vol. 5, Issue1, Mar., pp. 17-28.

[8] Hossam Mohamed Ali Ahmed, Mohamed El Gendy, Ahmed Mohamed Hassan Mirdan, Abdel Azim Mohamed Ali and Fahmy Salah Fahmy Abdel Haleem (2014): "Eff ect of corrugated beds on characteristics of submerged hydraulic jump", Ain Shams Engineering Journal, Vol. 5, Issue4, Dec., pp. 1033-1042.

[9] Sayed Mojtaba Razavi Nabavi and Mahmood Shafai Bejestan (2013): "Effects of Upward Seepage on Depth of Scour Hole Downstream of Free-Falling Jets Under Constant Tail Water Depth", Journal of Water Sciences Research, Spring 2013, Vol. 5, Issue 1, pp. 31-39.

[10] S.M.R. Nabavit and M. Shafai Bejestan (2012): "Bed upward seepage effects on scour dimensions downstream of freefalling jets", Ecology, Environment and Conservation, Vol. 18, Issue 1, Jan., pp. 183-186.

[11] M. Ghodsian, M. Mehraein and H.R. Ranjbar (2012): "Local scour due to free fall jets in non-uniform sediment", Scientia Iranica, Vol. 19, Issue 6, Dec., pp. 1437-1444.

[12] H. Hamidifar, M.H. Omid and M. Nasrabadi (2011): "Scour Downstream of a Rough Rigid Apron", World Applied Sciences Journal, Vol. 14, Issue 8, pp. 1169-1178.

[13] Abdelazim M. Ali and Yasser A. Mohamed (2010): "Eff ect of stilling basin shape on the hydraulic characteristics of the flow downstream radial gates", Alexandria Engineering Journal, Vol. 49, Issue 4, Dec., pp. 393-400.

[14] Subhasish Dey and Arindam Sarkar (2006): "Scour Downstream of an Apron Due to Submerged Horizontal Jets", Journal of Hydraulic Engineering, Vol.132, Issue 3, Mar., pp. 246-257.

[15] Samir Ali Ead and N. Rajaratnam (1998): "Double-Leaf Gate for Energy Dissipation Below Regulators", Journal of Hydraulic Engineering, Vol.124, Issue 11, Nov., pp. 1134-1145.

[16] S. S. Chatterjee, S. N. Ghosh, and M. Chatterjee (1994): "Local Scour due to Submerged Horizontal Jet", Journal of Hydraulic Research, Vol. 45, Issue 3, pp. 357-364.

[17] Ali Uyumaz (1988): "Scour Downstream of Vertical Gate”, Journal of Hydraulic Research, Vol. 114, Issue 7, pp. 811816.

[18] Javad Farhoudi and Kenneth V. H. Smith (1985): "Local scour profiles downstream of hydraulic jump", Journal of Hydraulic Research, Vol. 23, Issue 4, pp. 343-358.

[19] Trishan B. (2020): "Basis of Soil Classification" http://www.soilmanagementindia.com/soil/soil-classification/basis-ofsoil-classification/13460, Visited on: 4/1/2020. 